\title{
The Role of Forensic Accounting in Detecting Economic Crimes
}

\author{
Saman Udi Polycarp \\ Department of Accounting Federal University Wukari, Wukari Taraba State Nigeria
}

\begin{abstract}
The role forensic accounting plays in detracting crime and corruption in both public sector and private sector is the major focus of these journal. The objective of the research work seeks to discover the role a forensic accountant can play in the contest against crime by applying its investigative skills, providing litigation support service and documentation and reporting. The research design employed was the survey research. Data were majorly collected from primary sources. A well-structured 5 point likert scale questionnaire was used to elucidate information from the respondents, these results were analyzed using tables, simple percentages, and statistical analysis techniques chi-square and the results was used to validate or invalidate the hypotheses. The results of the empirical findings show that forensic accountants are relevant in investigating crime and corruption in both private and public sector in Nigeria. Forensic accountants play a role in litigation support services in organizational sector(s), and forensic accountants are relevant in documentation and reporting. It was detected that the forensic accountants play a significant role in shortening crime and corrupt practices in any sector since they provide a mechanism to hold people answerable, such that those who manage resources in a fiduciary capacity do not easily abuse that trust without detection. Amongst other proffered solutions, it was recommended that accounting professionals should always be proactive such that the members of the profession in Nigeria are kept abreast of emerging technologies, especially in the area of forensic accounting.
\end{abstract}

Keywords:Forensic Accounting, forensic accountants,economic and financial crime

DOI: $10.7176 / \mathrm{RJFA} / 10-16-11$

Publication date: August $31^{\text {st }} 2019$

\section{Introduction}

Even though the origin of Forensic Accounting could be traced to 1817 (Crumbley, 2001) and was coined in 1946 by Peloubet (Joshi, 2003), it is gaining dominance in fighting against economic and financial crimes. Economic and financial crimes (EFCs) have plagued every corner of the world's economies of which Nigeria is no exception. These crimes affect all firms and economies of nations (developed, developing and underdeveloped) (Ocansey, Adegbie\& Dada, 2015; Association of Certified Fraud Examiners, 2012). Therefore, several research works on the cost of these crimes were done. Kahan (2006) explained that continuous research confirmed a high demand of the prevention and uncovering of these economic and financial crimes by institutions and nations as a response to closer scrutiny of the economic and financial activities of shareholders and government agencies. However, economic and financial crimes are difficult to detect, and most of those detected are not reported for fear of bad publicity and loss of investor confidence. Forensic Accounting emerged in response to the high incidence of frauds (Modudgu\&Anyaduba, 2013; Ozkul\&Pamukcul, 2012). Forensic Accountants are perceived to have the training and skills needed to fight these economic and financial cankers. Therefore, the need to examine the application of forensic accounting and the combating of EFCs is very imperative. With this, the American Institute of Certified Public Accountants (AICPA) indicated that fraud accounting professionals would be in high demand in few years to come and developed Certified Financial Forensics (CFF) to increase the expertise of Certified Public Accountants (American Institute of Certified Public Accountants, 2008). Though auditing may uncover some economic and financial crimes, detailed disclosure of these crimes and their prosecution demand special techniques and forensic accounting is perceived to provide these techniques. Also, forensic accounting has the role of bridging audit expectation gap relating to fraud prevention, detection, and prosecution of economic and financial crime. Forensic accounting comprises investigation, litigation support and dispute resolution (Dada, Enyi\&Owolabi, 2013) and the upsurge in economic and financial crimes in countries and the world as a whole accentuated the need for the application of its techniques (Modugu\&Anyaduba, 2013). Consequently, forensic accounting is perceived as a tool for combating economic and financial crimes. Thus, the effective application of forensic accounting technique can investigate and detect economic and financial crime cases. Owolabi, Dada, and Olaoye (2013) added that forensic accountant might implement similar financial audit techniques, nonetheless with different objective and procedures; and may validate calculations needed by scrutinizing a trail of paperwork to achieve a specific goal of the engagement. Hence, the use of forensic accounting techniques could enhance the prosecution of economic and financial crime cases. It is therefore imperative to carry a research on economic and financial crimes and the relevance of forensic accounting techniques in detecting these crimes in Nigeria. Consequently, this research seeks to determine the role of forensic accounting technique in detecting economic and financial crimes in Nigeria. 


\section{Statement of problem}

The enactment of financial irregularities and economic crimes are flattering the common practice of both private and public sector in Nigeria as individual commits fraud and corrupt practices according to the capacity of their office. Subsequently, there is general anticipation that forensic accounting may be able to stern the flow of financial malfeasance witnessed in most sectors of the Nigerian economy. A nationwide study conducted by Kessler International showed that 39 percent of organizations have considered the need for a forensic accountant. The study intends to find out the role of forensic accounting in reduce the incidence of corporate fraud, economic crimes and mismanagement.

\section{Objective of study}

The wide-ranging objective of these study is to examine the role forensic accounting plays in detecting financial crimes. The specific objectives are to:

1. Determine if forensic accounting will be the right tool in confining management theft.

2. discover the mode in which forensic accounting detects financial crime.

3. Establish if forensic accounting really exposes financial crime.

\section{Hypotheses}

$\mathrm{H}_{0} 1$ : The application of forensic accounting services cannot prevent and detect fraud in Nigeria

$\mathrm{H}_{0} 2$ : Forensic accounting does not validate the true and four value of financial statements in Nigeria

$\mathrm{H}_{0} 3$ : Nigerian accountants are not adequately qualified to carryout forensic accounting practice.

\section{Literature review}

\section{The Concept of Forensic Accounting}

Forensic accounting is different from the old debit and credit accounting as it provides an accounting analysis that is suitable to the organization in resolving any dispute that may arise in such firms. Okoye (2006:34) defines accounting "as the process of identifying, measuring and communicating economic information to permit informed judgment and decision by the users of the information". More so, Oladipupo (2005) opined that financial investigation is an examination of the record and accounts of an organization for a special purpose. The integration of accounting, auditing and investigation yield the specialty known as forensic accounting. Forensic accounting is focused, therefore, upon both the evidence of economic transactions and reporting as contained within an accounting system, and the legal framework which allows such evidence to be suitable for the purpose of establishing accountability and/or valuation (Okolo, 2007). Simply put, forensic accounting is accounting that is suitable for legal review, offering the highest level of assurance, and including the now generally accepted connotation of having been arrived at in a scientific fashion (Crumbley, 2006). Forensic accounting remains the most challenging and sophisticated area in the financial sector. Although, the profession does not possess a formal definition, Razaee, Crumley and Elmore (2006) defined forensic and investigative accounting as "the application of financial skills and an investigative mentality to unresolved issues, conducted within the context of the rules of evidence." Forensic accounting in the view of Sheetz (2006) is simply the use of accounting discipline to help determine issues of facts in business litigation. Manning (2010) also defined forensic accounting as the application of financial accounting and investigative skills to a standard acceptable by the courts to address issues in disputes in the context of civil and criminal litigation. In the view Dimilola and Olofinsola (2007) forensic accounting is the application of accounting methods, investigative activities and law procedures to detect and investigate financial crimes and related economic misdeeds. However, Zysman (2006) sees forensic investigation as the utilization of specialized investigative skills in carrying out an inquiry conducted in such a manner that the outcome will have application to the court of law. As a discipline, forensic accounting encompasses financial expertise, fraud knowledge and a strong understanding of business reality and the working of the legal system. Its development can be achieved usually through on-the-job training and experience with investigating officers and legal counsel (Coenen, 2008; Tijani, 2006). Forensic accounting utilizes accounting, auditing and investigative skills while conducting an investigation. They often analyze, interpret, summarize and present information in a complex manner which is understandable and well documented. Also, they are often involved in various activities such as investigating and analyzing financial evidence, developing computerized system, exhibiting documents and presenting the evidence obtained, (Uche, 2009; Balarebe, 2009). Zysman (2006) sees forensic accounting as the integration of accounting, auditing and investigative skills. It provides an accounting analysis that is suitable to the court, which will form the basis of discussion, debate and ultimately dispute resolution. This means that forensic accounting is a field of specialization that has to do with provision of information that is meant to be used as evidence especially for legal purposes. The forensic accountants are trained to look beyond the numbers and deal with business reality of the situation (Coenen, 2008; Zysman, 2010). The court evidence indicates that a high level of expertise is necessary to analyze current complicated financial transactions and events (Razaee et al, 2006). This means that a forensic investigation may be applied in various fields such as accounting engineering, medicine, and some other disciplines (Owojori and Asaolu, 2009). Forensic accountants thrive on detecting fraud and criminal transactions in banks, corporate entities, public sector or from any other organisation's financial records. 
In other words, forensic accounting is all about the thrill of the hunting and discovering of inaccuracies. However, forensic accountants can be distinguished from external auditors by the assumption that auditors look at the numbers while forensic accountants look behind them (Balarebe 2009; Kasum, 2009). Forensic accounting should be sufficiently thorough and complete so that it can report its finding as to accounts, inventories or the presentation thereof that is of such quality that it would be sustainable in legal proceeding, or within some judicial or administrative review (Grazoli, Janals and Johnson, 2006; Williams 2010; Oladipupo, 2005).

\section{Effects of Fraud and Corruption in the Economy}

Fraud and corruption is so endemic that it is gradually becoming a normal way of life in Nigeria and other developing countries. Financial irregularities are so common that almost every individual cannot wash his or her hand clean of it (Oladipupo, 2005). From public officeholders to the managing directors of companies, individuals perpetrate fraud and corrupt practice according to the capacity of their office. Although financial irregularities affect both private and public sectors, the magnitude of public office fraud, together with the extent to which citizens are affected calls for much concern. The increase in financial crimes is making it difficult for Nigeria to meet her welfare and social responsibility to the citizenry. Uche (2009) asserts that high levels of financial abuses are hindering tax collection, making the enforcement of law difficult and discouraging foreign investment. Corruption and fraud have been responsible for Nigeria's comatose economy, capital flight, unemployment, insecurity, high level of poverty, stunted economic growth and development and a whole lot of other social vices in the country (Aderibigbe, 2010). Fraud and corruption are among the greatest obstacle to Nigeria's progress, development and advancement. Corruption and fraud also represents a significant additional cost of doing business in many developing countries. They undermine development by distorting the rule of law and weakening the institutional foundation upon which economic growth and development depends (Damilola and Olinfinsola 2007). The synopsis of all efforts at eradicating and eliminating corrupting from Nigeria clearly indicate that all such efforts have been met with vigorous resistance by the corrupt and very powerful segment of the Nigerian population. The falsities and frauds which are now being uncovered are responsible for the lack of capacity utilization in the Nigerian economy. And only recently, the Manufacturers Association of Nigeria (MAN) complained publicly, about how Nigerian banks are not helping matters of spurring economic development and progress through the infusion of needed resources into action production base of the economy (Aderibigbe, 2013; Nwachukwu and Maduka, 2012).

\section{Fraud and Forensic Accounting}

Forensic accounting services have not been so much in demand in the previous decades due to the relatively low level rate of fraud. But in growing spate of corporate scandals and collapse of corporate organizations (Izedonmi\&Ibadin 2012), instigated mainly by fraudulent activities of the management and people in position of managing and public funds have made the relevance of forensic accounting in building credibility and reliance on the operations more important. The importance of forensic accounting in cupping fraud is inevitable specifically in the Nigerian public sector where most management of the institutions are involved in one form of financial scandal or the other. Fraud is a factor of human desire to get rich quick. This criminality called fraud has eaten into the Nigerian system so deep that, it is now seen as regular behavior in Nigeria. The Institute of Turkish History explains the word fraud as "a deceptive trick, scam, game, artifice, cabal which is committed to cheat, mislead someone" and "contributing something useless to something in order to gain advantage" (Institute of Turkish History 1998). According to another definition, fraud is "to create a misjudgment or maintain an existing misjudgment to induce somebody to make a contract" (Arzova 2003). Fraud has no definite definition. Fraud can simply be put as an intentional act by an individual to deceive another individual in order to take possession of his/her financial or non-financial belongings for his/ benefit. The word "forensic" is defined by Black's Law Dictionary as "used in or suitable to courts of law or public debate." Therefore, "forensic accounting" is actually litigation support involving accounting. National Institute of Justice (NIJ) of United States Special Report (2007) defines forensic accounting as the application of accounting principles, theories, and disciplines to facts or hypotheses at issue in a legal dispute, and encompasses every branch of accounting knowledge. Also Bhasin (2007) say the integration of accounting, auditing and investigative skills creates the specialty known as forensic accounting.

Forensic accounting has been defined by Association of Certified Fraud Examiners (ACFE) as Forensic accounting is the use of professional accounting skills in matters involving potential or actual civil or criminal litigation, including, but not limited to, generally acceptable accounting and audit principles; the determination of lost profits, income, assets, or damages; evaluation of internal controls; fraud; and any other matter involving accounting expertise in the legal system. O“ zkul\&Pamukc (2012), states, forensic accounting uses accounting, auditing, and investigative skills to conduct investigations into theft and fraud. Hence, forensic accounting is basically knowledge that encompasses the understanding of accounting, auditing, investigation, legal, psychology, computer and criminology in providing evidence needed in a litigation process.According to Jafaru (2011), Forensic and investigative accounting should be seen as the application of financial skills and investigative mentality conducted within the context of the rules of evidence to resolve unresolved issues 
Bologna and Lindquist (1995) as quoted by Chariri (2009) stated that as an investigator, a forensic accountant can be seen as those who are specialist in fraud detection, and particularly in documenting exactly the kind of evidence required for successful criminal prosecution; able to work in complex regulatory and litigation environments; and with reasonable accuracy, can reconstruct missing, destroyed, or deceptive accounting records. Meanwhile, as economists, they are particularly effective at economic loss, damage, and social harm estimates; familiar with the assumptions, algorithms, and calculations in econometric models and opportunity cost scenarios; can measure and quantify such things as loss of goodwill and reputation. Finally, as appraisal experts, forensic accountants should be able to reliably express informed opinion on matters of business value, based on generally accepted theory; effective at evaluating the historical and projected degrees of risk and return of any going concern as well as any and all financial transactions involving assets, property, taxes, and equities.

\section{Empirical Review}

There have been researches in relation to forensic accounting both within and outside Nigeria. Izedonmi\&Ibadin (2012), examined forensic accounting and financial Crimes; looking at some basic and common financial crimes in corporate organizations, resting the focus on Nigeria, and by extension, the developing world. They revealed that the motivations for financial crimes are built around some risk factors, such as incentive (or pressure), opportunity and rationalization surrounding the financial criminals. Efiong, (2012), investigated the awareness of Forensic accounting among the Nigerian undergraduates. The study found that there is a very low level of awareness of forensic accounting among undergraduate students. And recommend increased awareness can be achieved via adoption of forensic accounting into the universities accounting curriculum to enhance students' skills and competencies. Eiyal, Otalor\&Awili, (2013) explore how forensic accounting can be employed in fighting financial crime in Nigeria. And concluded forensic accounting assignment is more comprehensive in nature than financial audit. This is because forensic accounting looks beyond the transactions and audit trail instead focus on substances of the transactions. Akhidime\&Uagbale-Ekatah (2014) in their exploration of the relevance of forensic accounting in Nigeria, found that though forensic have helped in fraud detection, it is lacking statutory backup. Hence it has no significant impact in tackling corruption in Nigeria. O” zkul\&Pamukc (2012) in their investigation into fraud detection and forensic accounting concluded that forensic accounting will be one of the best careers in the future and urge companies and government around the world to make material and moral investments for this profession, in order to ensure better world economy free of fraud. Bressler $(\mathrm{n} / \mathrm{d})$ researched on the role of attorney and judges' understanding of forensic accounting data as aid to litigation services. Stating that the judges' perception of Accounting Information Systems (AIS) is key in a judicial process, as it affects the jurors' position.

This research is a deviance from the above stated researches. The focus is on how the role forensic accounting has added to fraud detection and prevention.

\section{Methodology}

A survey research design is used in the study and the population of the study consists of 80 staff drawn from key government parastatals like the Central Bank of Nigeria (CBN), Federal Inland Revenue, Accounting Firms and Economic and Financial Crimes Commission (EFCC). The respondents were directors of finance, audit and assurance services, accounting technicians, IT directors and those identified as having justifiable views on forensic accounting and fraud detection in Nigeria and are involved at one stage or another in the preparation, analysis and usage of financial reports. They are therefore expected to be knowledgeable about the thrust of the study. A wellstructured 5 point likert scale questionnaire was used to elucidate information from the respondents. These results were analyzed using tables, simple percentages, and statistical analysis techniques chi-square and the results will be used to validate or invalidate the hypotheses. The findings will be discussed and conclusion will be drawn.

Model Specification

$x^{2}=\sum_{i=1}^{r}=\sum_{i=1}^{c}(\text { aij }-\mathrm{eij})^{2} / e i j$

Where:

oij = observed frequency in ith row and jth column

eij = expected frequency in the ijth cell

eij $=($ ith row total $x$ jth column total $) /$ grand total

With degree of freedom $=(\mathrm{r}-1)(\mathrm{c}-1)$

$\mathrm{c}=$ column

$\mathrm{r}=$ row

$1=$ constant 


\section{Decision rule}

Reject $\mathrm{H}_{0}$ : if $x^{2}$ calculated is greater than $x^{2}$ tabulated

Don't Reject $\mathrm{H}_{0}$ : if $x^{2}$ calculated is less than $x^{2}$ tabulated

\section{Data presentation, analysis and interpretation}

Data analysis is the categorizing of data to obtain answers to research questions. The questionnaire was designed and administered to respondents and a total of 80 questionnaires were administered and all 80 questionnaires were properly filled representing $100 \%$ response rate from respondents. This is presented in the table below:

\section{CHART 1: Questionnaire administered, showing those returned and the number not returned.}
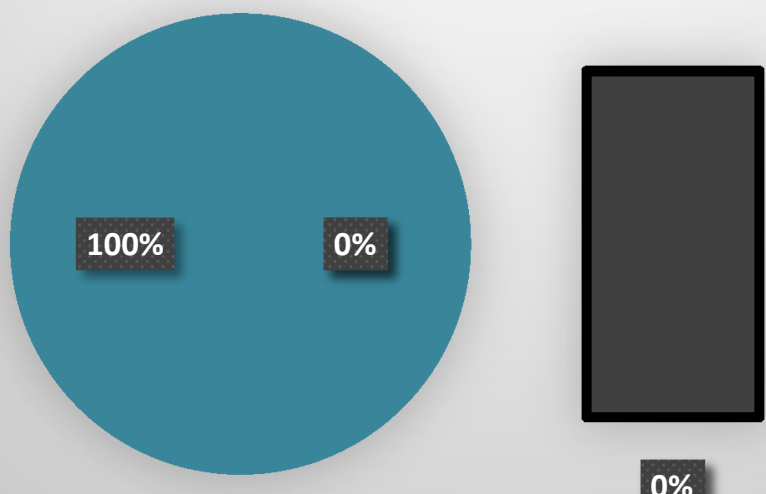

RETURNED

NOT RETURNED

Source: field survey, 2019

The chart below shows the sex distribution of respondents

\section{CHART 2: Sex Distributions.}

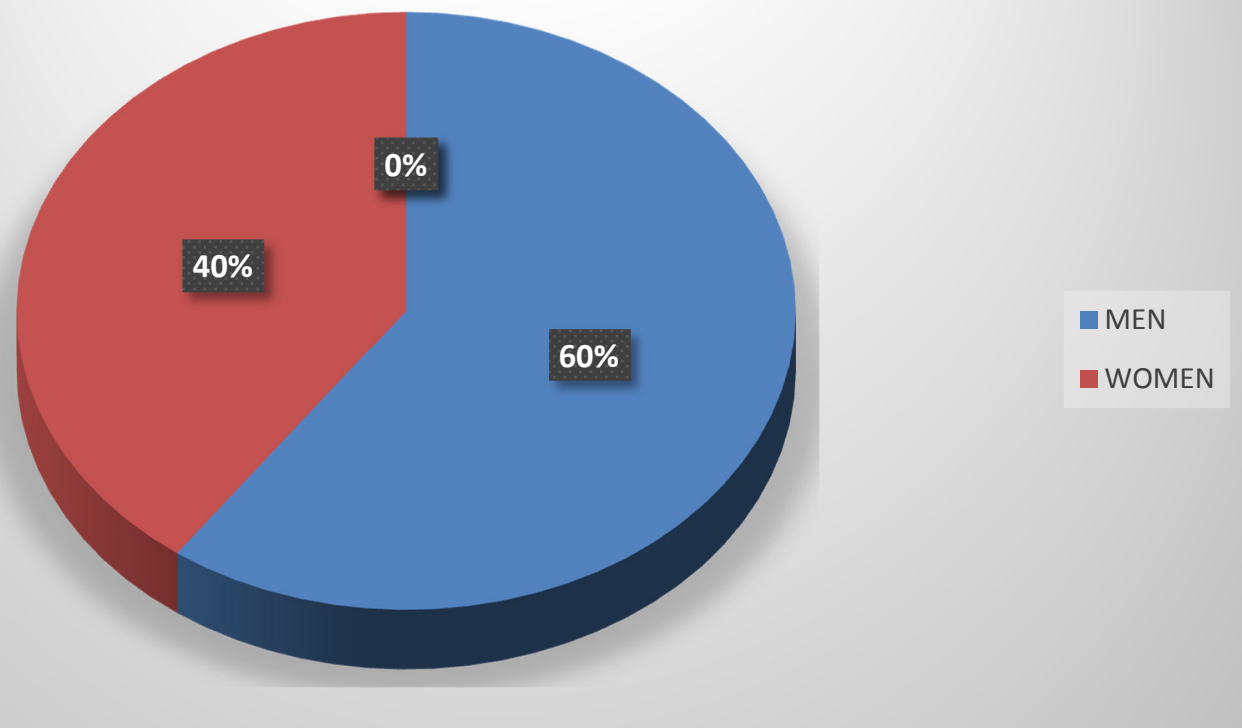

Source: field survey, 2019.

Chart 2 above shows that $60 \%$ of respondents are men while $40 \%$ are women. This gives us a satisfactory platform for analysis in respects to this study. 


\section{CHART 3: Number of Years Working In that Sector}

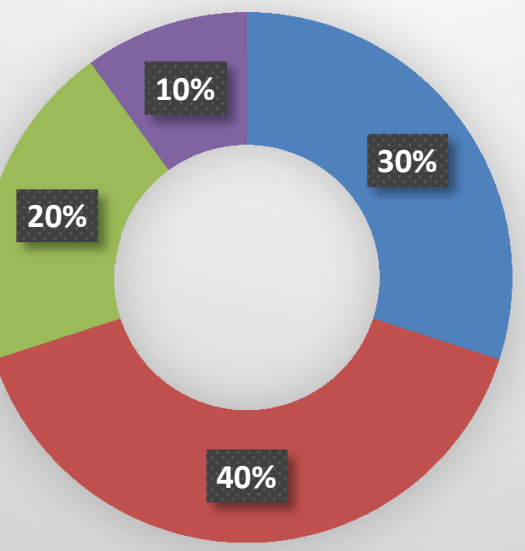

- 0-10

-11-20

21-30

31 \& above

Source: field survey, 2019.

Chart 3 above shows that $30 \%$ of respondent have been on active service form $0-10$ years, $40 \%$ of respondent have been on active service for 11-20 years, $20 \%$ of respondent have been on active service for 21-30 years, while $10 \%$ of respondent have been on active service for 31 years and still counting.

\section{CHART 4: MARITAL DISTRIBUTIONS}

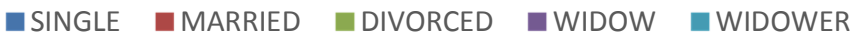

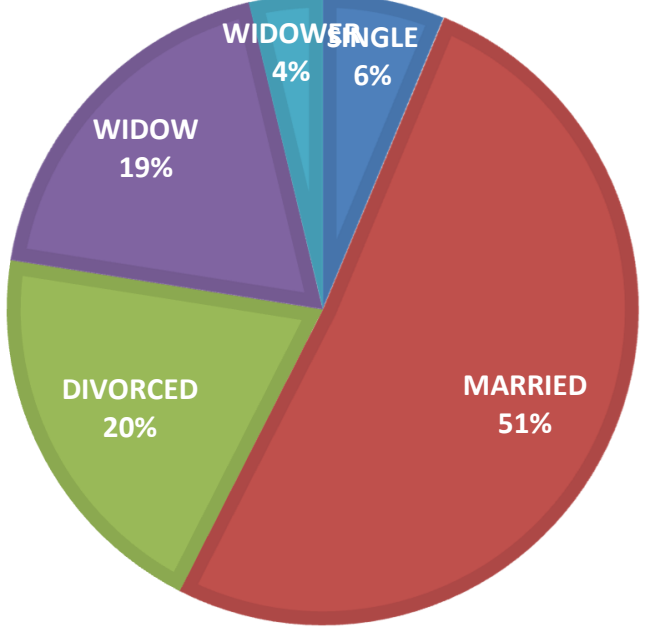

Source: field survey, 2019.

Chart 4 above shows that $6 \%$ of respondent are single and $51 \%$ of respondent are married, $20 \%$ of respondent are Divorced, $19 \%$ of respondent are Widow, and 4\% of respondent are Widower. 


\section{TEST OF HYPOTHESES}

$\mathrm{H}_{0}$ : The application of forensic accounting services cannot prevent and detect fraud in Nigeria

Contingency table

\begin{tabular}{|c|c|c|c|c|c|c|c|c|c|c|c|}
\hline QUESTION & $\begin{array}{l}\text { SA } \\
\text { oij }\end{array}$ & (eij) & $\begin{array}{l}\text { A } \\
\text { oij }\end{array}$ & (eij) & $\begin{array}{l}\mathrm{U} \\
\text { oij }\end{array}$ & (eij) & $\begin{array}{l}\mathrm{D} \\
\text { oij }\end{array}$ & (eij) & $\begin{array}{l}\text { SD } \\
\text { oij }\end{array}$ & (eij) & TOTAL \\
\hline $\begin{array}{l}\text { Forensic accounting } \\
\text { service help in } \\
\text { detect fraud }\end{array}$ & 72 & 61.67 & 8 & 81.33 & 0 & 0 & 0 & 0 & 0 & 0 & 80 \\
\hline $\begin{array}{l}\text { Forensic accounting } \\
\text { provide room for } \\
\text { fraud prevention }\end{array}$ & 33 & 61.67 & 47 & 81.33 & 0 & 0 & 0 & 0 & 0 & 0 & 80 \\
\hline $\begin{array}{l}\text { The use of forensic } \\
\text { accounting service } \\
\text { minimize fraud as } \\
\text { individuals who } \\
\text { want to commit } \\
\text { fraud need a double } \\
\text { thought }\end{array}$ & 80 & 61.67 & 0 & 81.33 & 0 & 0 & 0 & 0 & 0 & 0 & 80 \\
\hline Total & 185 & & 55 & & 0 & & 0 & & 0 & & 240 \\
\hline
\end{tabular}

Chi-square Table

oijeijoij-eij[oij-eij] ${ }^{2}$

$[01 j-\mathrm{e} 1 \mathrm{j}]^{2 / \mathrm{e} 1 \mathrm{j}}$

$\begin{array}{lrrrc}72 & 61.67 & 10.33 & 106.71 & 1.73 \\ 33 & 61.67 & -28.67 & 821.97 & 13.33 \\ 80 & 61.67 & 18.33 & 335.99 & 5.45 \\ 8 & 18.33 & -10.33 & 106.71 & 5.82 \\ 47 & 18.33 & 28.67 & 821.97 & 44.84 \\ 0 & 18.33 & -18.33 & 335.99 & 18.33 \\ \text { field survey, } 2019 . & & & 89.5\end{array}$

Source: field survey, 2019.

Chi-square calculated $\left(\begin{array}{ll}x & \mathrm{c}\end{array}\right)=89.5$

$\mathrm{df}=(\mathrm{r}-1)(\mathrm{c}-1)$

$\mathrm{df}=(5-1)(3-1)$

$\mathrm{df}=(4)(2)$

$\mathrm{df}=8$.

At $5 \%$ degree, the critical value will be $x \quad 0.05=15.507$

Conclusion: We reject Ho and accept H1 this is because the calculated value of chi-square $(x \quad)=89.5$ is greater than the acceptance region above.

Test of hypotheses two (2)

$\mathrm{H}_{0}$ : Forensic accounting does not validate the true and four value of financial statements in Nigeria

Contingency table

\begin{tabular}{|c|c|c|c|c|c|c|c|c|}
\hline QUESTION & $\begin{array}{l}\text { SA } \\
\text { oij } \quad \text { (eij) }\end{array}$ & $\begin{array}{l}\text { A } \\
\text { oij } \quad \text { (eij) }\end{array}$ & $\begin{array}{l}\mathrm{U} \\
\text { oij } \quad \text { (eij) }\end{array}$ & $\begin{array}{l}\mathrm{D} \\
\text { oij }\end{array}$ & (eij) & $\begin{array}{l}\text { SD } \\
\text { oij } \\
\end{array}$ & (eij) & TOTAL \\
\hline $\begin{array}{l}\text { Forensic accounting shows } \\
\text { the true value of an } \\
\text { organization } \\
\text { statements. }\end{array}$ & $\begin{array}{ll}79 & 54.33\end{array}$ & $\begin{array}{ll}1 & 23.33\end{array}$ & $0 \quad 2.33$ & 0 & 0 & 0 & 0 & 80 \\
\hline $\begin{array}{l}\text { Forensic accounting exposes } \\
\text { any hidden fraud in any } \\
\text { financial statement }\end{array}$ & 1254.33 & 6123.33 & 72.33 & 0 & 0 & 0 & 0 & 80 \\
\hline $\begin{array}{l}\text { Forensic accounting is an } \\
\text { operational tool to confirm } \\
\text { unauthorized transfer of } \\
\text { money }\end{array}$ & 7254.33 & 823.33 & 2.33 & 0 & 0 & 0 & 0 & 80 \\
\hline Total & 163 & 70 & 7 & 0 & & 0 & & 240 \\
\hline
\end{tabular}


Chi-square Table

\begin{tabular}{|c|c|c|c|c|}
\hline oijeijoij-eij & [oij-eij] ${ }^{2}$ & {$[$ oij-eij] $/ 2 /$ eij } & & \\
\hline 79 & 54.33 & 24.67 & 608.61 & 11.20 \\
\hline 12 & 54.33 & -42.33 & 1791.83 & 32.98 \\
\hline 72 & 54.33 & 17.67 & 312.23 & 5.75 \\
\hline 1 & 23.33 & -22.33 & 498.63 & 21.37 \\
\hline 61 & 23.33 & 37.67 & 1419.03 & 60.82 \\
\hline 8 & 23.33 & -15.33 & 235.01 & 10.07 \\
\hline 0 & 2.33 & -2.33 & 5.43 & 2.33 \\
\hline 7 & 2.33 & 4.67 & 21.81 & 9.36 \\
\hline 0 & 2.33 & -2.33 & 5.43 & 2.33 \\
\hline
\end{tabular}

Source: field survey, 2019 .

156.21

Chi-square calculated $\left(\begin{array}{ll}x & \mathrm{c}\end{array}\right)=156.21$

$\mathrm{df}=(\mathrm{r}-1)(\mathrm{c}-1)$

$\mathrm{df}=(5-1)(3-1)$

$\mathrm{df}=(4)(2)$

$\mathrm{df}=8$.

2

At $5 \%$ degree, the critical value will be $x \quad 0.05=15.507$

2

Conclusion: We reject Ho and accept H1 this is because the calculated value of chi-square $\left(x^{2}\right)=156.21$ is greater than the acceptance region above.

Test of hypotheses three (3)

$\mathrm{H}_{0}$ : Nigerian accountants are not adequately qualified to carryout forensic accounting practice.

Contingency table

\begin{tabular}{|c|c|c|c|c|c|c|c|c|c|}
\hline QUESTION & $\begin{array}{ll}\text { SA } & \\
\text { oij } & \text { (eij) }\end{array}$ & $\begin{array}{ll}\mathrm{A} & \\
\text { oij } & \text { (eij) }\end{array}$ & $\begin{array}{l}U \\
\text { oij }\end{array}$ & (eij) & $\begin{array}{l}\mathrm{D} \\
\text { oij }\end{array}$ & (eij) & $\begin{array}{l}\text { SD } \\
\text { oij }\end{array}$ & (eij) & TOTAL \\
\hline $\begin{array}{l}\text { The country has adequate } \\
\text { qualified accountants that } \\
\text { can carry out forensic } \\
\text { accounting practices }\end{array}$ & $\begin{array}{ll}33 & 64.33\end{array}$ & 3913.33 & 7 & 2.33 & 1 & 0.33 & 0 & 0 & 80 \\
\hline $\begin{array}{l}\text { The country has accredited } \\
\text { institutions that train } \\
\text { individuals/accountants on } \\
\text { forensic accounting }\end{array}$ & $\begin{array}{ll}80 & 64.33\end{array}$ & 13.33 & 0 & 2.33 & 0 & 0.33 & 0 & 0 & 80 \\
\hline $\begin{array}{l}\text { Accountants in the country } \\
\text { has great knowledge on } \\
\text { forensic accounting }\end{array}$ & $\begin{array}{ll}80 & 64.33\end{array}$ & 13.33 & 0 & 2.33 & 0 & 0.33 & 0 & 0 & 80 \\
\hline Total & 193 & 39 & 7 & & 1 & & 0 & & 240 \\
\hline
\end{tabular}

Chi-square table

oijeijoij-eij [oij-eij] ${ }^{2}$

$[o i j-e i j]^{2 / ~ e i j ~}$

$\begin{array}{ccccc}33 & 64.33 & -31.33 & 981.57 & 15.26 \\ 80 & 64.33 & 15.67 & 245.55 & 3.82 \\ 80 & 64.33 & 15.67 & 245.55 & 3.82 \\ 39 & 13.33 & 25.67 & 658.95 & 49.43 \\ 0 & 13.33 & -13.33 & 177.69 & 13.33 \\ 0 & 13.33 & -13.33 & 177.69 & 13.33 \\ 7 & 2.33 & 4.67 & 21.81 & 9.36 \\ 0 & 2.33 & -2.33 & 5.43 & 2.33 \\ 0 & 2.33 & -2.33 & 5.43 & 2.33 \\ 1 & 0.33 & 0.67 & 0.45 & 1.36 \\ 0 & 0.33 & -0.33 & 0.11 & 0.33 \\ 0 & 0.33 & -0.33 & 0.11 & 0.33\end{array}$

Source: field survey, 2019.

115.03 
Chi-square calculated $(x \quad \mathrm{c})=115.03$

$\mathrm{df}=(\mathrm{r}-1)(\mathrm{c}-1)$

$\mathrm{df}=(5-1)(3-1)$

$\mathrm{df}=(4)(2)$

$\mathrm{df}=8$.

At $5 \%$ degree, the critical value will be $\chi \quad 0.05=15.507$

Conclusion: We reject Ho and accept H1 this is because the calculated value of chi-square $(x \quad)=115.03$ is greater than the acceptance region above.

\section{Summary of findings}

From the result of findings, the researchers emerged with the following:

(1) Using the hypothesis set by the researcher, a test was made using the chi-square $(x)$ statistics and it shows that the application of forensic accounting services can prevent and detect fraud in Nigeria.

(2) For the second and third objective of this research work, judging from the hypotheses tested, it has been clearly indicated that forensic accounting validate the true and four values of financial statements in Nigeria.

(3) In pursuance of the last objective, a test of hypothesis has proved that Nigeria accountants are adequately qualified to carryout forensic accounting practice.

\section{Conclusion and recommendation}

Forensic accounting and the forensic accountants play significant roles in the curbing of crimes and corruption in both private and public sector. The following findings were made from this study:

- The relevance of forensic accounting is growing worldwide as rising crimes, corruption, malfunctioning of regulators, security scams and many up-coming issues of this kind all are openly indicating the increasing demand for forensic accountants.

- The forensic accountant plays an important role in litigation support services.

It is therefore recommended that the forensic accountant, in fighting crimes and corruption, has a better advantage within his distinct functions or roles performed compared to the regular auditor. If Nigeria desires to be 'deranked' as the most corrupt nation by Transparency International, she must rush to embrace this emerging trend in the accounting profession so that crimes and corruption can be combated adequately both in the private sector and most especially the public sector of the nation.

Furthermore, this is the age of knowledge economy and the accountancy professional bodies should increase their effort in providing functional and cutting edge education to their members and develop curriculum that would incorporate forensic accounting with a view to make them globally competitive.

Also, Educational institutions should lead the way while the legislative arm of government should enact legislations that will not make all anti-graft, financial crimes and corruption agencies to not only be autonomous, but effective and efficient in performing their duties. It is not when a corrupt government official has lost face with powers that be that he should face investigation and trials.

To sum up, it is no doubt this study could not have covered all areas of forensic accounting. It is therefore suggested that other researchers expand to the private sector and even increase the population to be covered. In an economy such as the Nigerian economy, forensic accounting is needed as it goes deeper to uncover fraud and hidden records.

\section{References}

Adewumi, B. and Toluyemi, T. (2000): Auditing and Corporate Transparency, Lagos: Evans Pub. Nig.

Akhidime and Uagbale-Ekatah (2014): "The growing relevance of forensic accounting as a tool for combating fraud and corruption: Nigerian Experience" Research Journal of Finance and Accounting: 5(2).

Albrecht, W.S. (2005): Identifying fraudulent financial transaction: A framework for detecting financial statement fraud. Brigham: Brigham Young University.

Bhasin, M. (2007): "Forensic Accounting: A new paradigm for riche consulting". The Chartered Accountant $1000-1010$.

Coenen, T.L. (2005) “Forensic Accounting, a new twist on being an accountant.” Tracy@squenceinc.com

Crumbley, D.L. (2001): "Forensic Accounting: older than you think". JFA 2(2)181.

David, M. (2008): The Role of forensic Accountant. Toronto Ontario

Degboro, D; and J. Olufinsola (2007): "Forensic Accountants and the litigation support engagement". Nigerian Accountant 40(2), 49-52.

Enofe, A.O; Izvbigie, D.P.I; and Usifo, E.J. (2015): "Impact of confidential privilege or forensic accountantin litigation support services". West African Journal of Business and Management Science 
Enyi, R. (2009): "Fraudulent Activities in manufacturing processes". International Journal of Business andsocial science 4 (7); 289-293.

Gray, O.R; and Moussah, S.D. (2006): "Forensic Accounting and Auditing United again: A historical perspective" Journal of Business issues No. 2 pp. 15-25Available at SSRNhttp://ssrn.com/abstract=1642100.

Izedomin, F.I; and Mgbame, C.O. (2011): "Curbing financial frauds in Nigeria: A case for forensicAccounting" African Journal of Humanities \& Society, 1(12)52-56.

Mukoro, D.O. Faboyede, S.O. and Edafejirhaye, V. I (2011). Forensic Accounting and Fraud Management Perspective: An Integrated Approach. H-Link Excel, Lagos.

Nye, J.(1967) Corruption and Political Development: A Cost-benefit Analysis, American political science review, Vol.16, No2, June 1967

Oguma, S.(2011) Why We Train Our Members in Forensic Accounting. The Nigerian Accountant, April/June 2011.Vol.22.N2 (p.15)

Ojo, M. (2012) Forensic Accounting and The Law: The Forensic Accountant in the Capacity of an Expert Witness. Retrieved from http://ssm:com/abstract $=2026071$

Rezace, Z; Crumbley, D.L; and Elmore, R.C. (2006): "Forensic Accounting Education: A Survey of Academicians and Practitioners". Journal of forensic Accounting 10(3):48-59.

Zysmen, A. (2004): Forensic Accounting Demystified. World Investigators Network, Standard Practive for Investigation and forensic Accounting Engagements.Canadian Institute of Chartered Accountants.

\author{
Appendix \\ INSTRUCTION \\ Please tick or mark (v) in the boxes provided or fill where appropriate \\ SECTION A: PERSONAL DATA \\ 1. Sex: Male [ ] Female [ ] \\ 2. Number of years working with the sector: 0-10 [ ] 11-20 [ ] 21-30 [ ] 31-above [ ] \\ 3. Marital status: Single [ ] Married [ ], Divorced [ ] Widow [ ] Widower [ ] \\ SECTION B: QUESTIONS TO TEST THE STUDY HYPOTHESES \\ TO DETERMINE IF FORENSIC ACCOUNTING WILL BE THE RIGHT TOOL IN CONFINING \\ MANAGEMENT THEFT.
}

1. Forensic accounting service help in detect fraud

(a) strongly agree (b) agree (c) undecided (d) Disagree (e) Strongly disagree

2. $\quad$ Forensic accounting provide room for fraud prevention

(a) strongly agree (b) agree (c) undecided (d) Disagree (e) Strongly disagree

3. The use of forensic accounting service minimize fraud as individuals who want to commit fraud need a double thought

(a) strongly Agree (b) Agree (c) undecided (d) disagree (e) strongly disagree

TO DISCOVER THE MODE IN WHICH FORENSIC ACCOUNTING DETECTS FINANCIAL CRIME.

4. Forensic accounting shows the true value of an organization financial statements.

(a) strongly agree (b) agree (c) undecided (d) Disagree (e) Strongly disagree

5. Forensic accounting exposes any hidden fraud in any financial statement

(a) strongly agree (b) agree (c) undecided (d) disagree (e) Strongly disagree

6. Forensic accounting is an operational tool to confirm unauthorized transfer of money

(a) strongly agree (b) agree (c) undecided (d) Disagree (e) Strongly disagree

TO ESTABLISH IF FORENSIC ACCOUNTING REALLY EXPOSES FINANCIAL CRIME.

7. The country has adequate qualified accountants that can carry out forensic accounting practices

(a) strongly agree (b) agree (c) undecided (d) Disagree (e) Strongly disagree

8. The country has accredited institutions that train individuals/accountants on forensic accounting

(a) strongly agree (b) agree (c) undecided (d) Disagree (e) Strongly disagree

9. Accountants in the country has great knowledge on forensic accounting

(a) strongly agree (b) agree (c) undecided (d) Disagree (e) Strongly disagree 